NBER WORKING PAPER SERIES

\title{
SUDDEN STOPS, THE REAL EXCHANGE RATE, AND FISCAL SUSTAINABILITY: ARGENTINA'S LESSONS
}

\author{
Guillermo A. Calvo \\ Alejandro Izquierdo \\ Ernesto Talvi \\ Working Paper 9828 \\ http://www.nber.org/papers/w9828
}
NATIONAL BUREAU OF ECONOMIC RESEARCH 1050 Massachusetts Avenue
Cambridge, MA 02138
July 2003

We want to thank Ricardo Caballero, Enrique Mendoza and Rick Mishkin for very useful comments and Luis Fernando Mejía for excellent research assistance. The views expressed in this document are the authors' and do not necessarily reflect those of the Inter-American Development Bank or the National Bureau of Economic Research

(C2003 by Guillermo A. Calvo, Alejandro Izquierdo, and Ernesto Talvi. All rights reserved. Short sections of text not to exceed two paragraphs, may be quoted without explicit permission provided that full credit including (C) notice, is given to the source. 
Sudden Stops, the Real Exchange Rate, and Fiscal Sustainability: Argentina's Lessons Guillermo A. Calvo, Alejandro Izquierdo, and Ernesto Talvi NBER Working Paper No. 9828

July 2003

JEL No. F34, F41, E61

\section{$\underline{\text { ABSTRACT }}$}

We offer an alternative explanation for the fall of Argentina's Convertibility Program based on the country's vulnerability to Sudden Stops in capital flows. Sudden Stops are typically accompanied by a substantial increase in the real exchange rate that breaks havoc in countries that are heavily dollarized in their liabilities, turning otherwise sustainable fiscal and corporate sector positions into unsustainable ones. In particular, we stress that the required change in relative prices is larger the more closed an economy is in terms of its supply of tradable goods. By contrasting Argentina's performance relative to other Latin American countries that were also subject to the Sudden Stop triggered by the Russian crisis of 1998, we identify key vulnerability indicators that separated Argentina from its piers. We also provide an explanation for the political maelstrom that ensued after the Sudden Stop, based on a War of Attrition argument related to the wealth redistribution conflict triggered by the Sudden Stop and fiscal collapse. This framework also provides elements to rationalize the banking crisis that accompanied the fall of Convertibility.

Guillermo A. Calvo

Inter-American Development Bank 1300 New York Ave,N.W.

Stop W-0430

Washington D.C., 20577

and NBER

calvo@econ.umd.edu

Alejandro Izquierdo

Inter-American Development Bank 1300 New York Ave,N.W.

Stop W-0436

Washington D.C., 20577

alejandroi@iadb.org

Ernesto Talvi

CERES

Antonio Costa 3476

CP11300

Montevideo

Uruguay

etalvi@ceres-uy.org 


\section{Introduction}

The fall of the Convertibility Program (i.e., the currency board regime) in Argentina has stirred a lively discussion about the causes for its collapse. Several explanations have been offered. The most popular one relates to the unholy combination of a fixed exchange rate and large fiscal deficits that led to a rapid growth in public debt, severe fiscal sustainability problems, and eventually, a loss of access to the credit markets. Another popular view stresses the impact of a fixed exchange rate regime coupled with devaluation by Argentina's major trading partners as an important cause of real exchange rate (RER) misalignment, which reduced profitability in the tradable sector. This, in turn, slowed down investment and led the economy into a protracted recession as it deflated away the RER disequilibrium.

The purpose of this paper is to provide a different interpretation of the collapse of Convertibility, which places special emphasis on two key structural characteristics of Argentina's productive and financial structure and on political economy considerations.

Our point of departure is the Russian crisis of August 1998, which drastically changed the behavior of capital markets. We believe that developments at the center of capital markets were key to producing an unexpected, severe, and prolonged stop in capital flows (hereon referred to as Sudden Stop, SS) to Emerging Market economies, and Latin America was no exception.

We will argue that in the case of Argentina two considerations played a crucial role in magnifying the effect of the sudden stop in capital flows and in creating the fiscal and financial problems that eventually Argentina had to confront, namely: 
a) A relatively closed economy, i.e., an economy with a small share of tradable goods output (more specifically, output that could swiftly be transformed into exports) relative to domestic absorption of tradable goods;

b) Liability Dollarization (more specifically, large financial currency-denomination mismatches) in both the private and public sector.

Being closed implies that the Sudden Stop (SS) may call for a sharp increase in the equilibrium real exchange rate, RER (i.e., real depreciation). Liability Dollarization, in turn, entails foreign-exchange-denominated debt in "peso producing" sectors (mostly non-tradables) including the government, which implies large balance sheet effects when the RER rises. Thus, these two factors represented a dangerous financial cocktail for both the private sector and the government.

Argentina's Fall from Paradise could be rationalized by its commercial closed-ness, and penchant for dollar indexation in the corporate sector. In that sense, the tragedy needs no fisc to grab one's imagination. Under liability dollarization the need for a sharp (equilibrium) real devaluation in the aftermath of the SS hit first and foremost corporate balance sheets. Perhaps more importantly, it lowered the collateral of non-tradable sectors, which, by and of itself, brings about a stock retrenchment of credit to the nontradable sector (see, for example, Izquierdo, 1999 ${ }^{1}$ ). Hence, to the first exogenous Sudden Stop, a second round follows, which validates and likely deepens the impact of the first.

\footnotetext{
1 This model assumes that non-tradable collateral is accepted by foreign creditors. In other models, such as Caballero and Krishnamurty, 2003, where only tradable collateral is accepted and assumed to be fixed, falls in the price of non-tradables do not have an effect on output because tradable collateral remains unaffected. Even if this were the case, crises of this magnitude, which bring along fiscal un-sustainability, could also alter the amount of tradable collateral since the tradable sector may be exposed to confiscation from the public sector.
} 
This kind of shock can only be met by a sale of assets, financial restructuring or the initiation of bankruptcy procedures. No flow "belt tightening" of the corporate sector could probably do the trick. The problem here, though, is that the shock hits a whole sector, not just an individual firm. Prospects for individual firms are hard to assess when they belong to a network immersed in financial difficulties. Thus, assets can only be sold at rock-bottom prices, and financial restructurings and bankruptcy procedures are especially hard and time consuming, which precipitate the economy into a protracted recession. Under these circumstances, cries for help will likely rise from every corner, and it will be politically very difficult for the government to stay put and wait for the dust to settle - thus, unavoidably bringing into play strong and complex political economy factors.

A strong fisc could have come to the rescue by effectively socializing private debts or providing additional collateral (like in Korea's IMF-orchestrated bank negotiations with external creditors in 1997, which eventually resulted in a rise in public debt equivalent to more than 30 percent of GDP). As argued in Calvo, 2002b, the government can play an important role in cases in which the economy is hit by lowprobability shocks, like the aftermath of the Russian 1998 crisis. $^{2}$ However, and this is when the fisc kicks in, given the financial structure of the public sector, Argentina's government was also exposed to exactly the same financial problems as the private sector following the SS and the RER rise. The government thus became part of the problem rather than (as in Korea) part of the solution. But our view departs from the fiscalist view

\footnotetext{
${ }^{2}$ The Russian crisis was not a low probability event. Savvy investors knew that sooner or later a crisis was likely to erupt. Our claim, however, is that it was hard to even imagine, ex ante, that a crisis in a country that represents less than 1 percent of world output would have such devastating effect on the world capital market.
} 
of the Convertibility's demise. Argentina was fiscally weak (i.e. vulnerable to a Sudden Stop) not because it had an unreasonably large current (flow) fiscal deficit -which it did not- inconsistent with the fixed exchange rate regime. Argentina's fiscal weakness lay in that the government was unable to offset the fundamental vulnerabilities associated with the country's closed-ness and Liability Dollarization, the latter impinging upon both public and private debt.

Adding together private and public debt, and computing its share in GDP after the Sudden Stop (involving a higher RER), it is clear that Argentina's debt was dangerously high, as early as 1999. For the sake of the argument, consider the case in which the government socializes the larger GDP-equivalent debt incurred by corporates after such change in the RER (which, as will be argued, hovers around 60 percent). Under those circumstances, we will argue that the government would have been required to produce a permanently larger primary surplus in excess of 3\% of GDP. Permanently is a key word. Sustaining higher levels of debt by implicitly collateralizing it with future flows of primary surpluses is an extraordinarily difficult task since, for starters, future flows depend on future governments. If credibility on future surpluses is at stake, the ability to roll over the stock of debt would be severely hampered, creating a stock retrenchment problem for the government, potentially as severe as that suffered by the private sector. To illustrate this point, it is sufficient to say that a failure to produce such an adjustment of the primary surplus on a permanent basis would have implied a $75 \%$ haircut on the existing debt.

To avoid a painful default, Argentina had to permanently and credibly raise its primary surpluses. This could only occur by raising taxes or reducing primary spending. 
Raising taxes is particularly problematic when the corporate sector itself is under severe financial stress and arrears with the public sector become very significant as a source of financing. ${ }^{3}$ As a result, raising taxes on the non-corporate sector and /or reducing primary expenditures were the only options available, absent debt restructuring.

The government was thus forced to engage in wealth redistribution policies across sectors. This is where politics kicks in with full force, and phenomena like War of Attrition among different groups in society develop. Wealth redistribution sets in motion a tug-of-war in which decisions are delayed and, as the War of Attrition literature shows (see Sturzenegger and Tommasi, 1998), can be highly disruptive. Thus, unless a supranational entity generates a cooperative equilibrium, the impasse may take a long time to resolve and may seriously deepen the extent of the crisis. Since no positive rate of return can match losing a chunk of capital to the taxman's ax, this impasse in resolving which sectors would ultimately sustain the losses, brought about a grinding stop to all investment projects, except for those few that could be safely shielded from the bloodbath (e.g., black-market transactions). Under these circumstances, tax revenue falls, further weakening the government's fiscal situation. This, in turn, increases the expected devaluation and sets in motion a new wave of credit cuts.

At this stage, politically feasible solutions were inevitably going to involve spreading the cost of adjustment among all players, making some type of debt restructuring inevitable. In turn, expectations of debt restructuring would severely hit the banking system to the extent that most of its assets consisted of government debt and dollar loans to non-tradable sectors. It should therefore come as no surprise that a bank run materialized as a corollary of the Sudden Stop.

\footnotetext{
${ }^{3}$ Moreover, under the corporate bailout scenario assumed above, this option would simply not be available.
} 
Finally, a word on the role of the Convertibility regime itself. Argentina's adherence to its hard peg to the dollar probably made things worse, but for reasons not necessarily related to competitiveness. As argued in Talvi (1997), incomplete but inevitable adjustments can mask the gravity of the underlying fiscal situation. In the case of Argentina, maintaining the peg and delaying the inevitable adjustment of the RER may have contributed to conceal the true nature of its financial problems for a long period of time, leaving politicians and the general public largely unaware of the gravity of the financial situation, a factor that might have contributed to undermine the political support for the necessary fiscal and financial adjustments. Furthermore, maintaining the peg left Argentina without a valuable instrument of the adjustment package, namely, inflation, which has proven, time and again, to be a very powerful tool for lowering government expenditure (in real terms).

The paper is organized as follows: Section 2 examines capital market trends in Latin America following the Russian crisis of 1998 and provides a rationale for Sudden Stop behavior. Specifically, we show that the nature of Sudden Stops has typically been large and persistent. Section 3 dwells on conditions under which Sudden Stops lead to a sharp depreciation of the RER, and ranks a set of Latin American countries in terms of vulnerability to these shocks. Section $\mathbf{4}$ focuses more closely on Argentina. It discusses fiscal sustainability and determines the sources of vulnerability to swift changes in the RER, and computes how those changes affected Argentina's fiscal position. Section 5 dwells on the effects of RER adjustment on the materialization of contingent liabilities (particularly those arising from currency-denomination mismatches in the corporate sector). We compute how Argentina's fiscal position would have deteriorated even 
further under the assumption that the government would attempt (as it eventually did) to bail out the corporate sector. Section 6 briefly touches upon the concealment of the financial problems under Argentina's hard peg, and analyzes likely performance under a floating exchange rate regime following a Sudden Stop. The paper concludes with some policy lessons for Latin America that emerge from Argentina's experience, and an Appendix that reviews the policies followed by Argentina.

\section{The World Scene after Russia}

Russia's August 1998 crisis represents a milestone in the development of emerging capital markets. Massive capital inflows that set sail to Latin America in the early 1990s, financing high growth rates and large current account deficits, came all of a sudden to a standstill following Russia's partial foreign debt repudiation in August, 1998. It was hard to imagine how a crisis in a country with little if any financial or trading ties to Latin America could have such profound effects on the region. This puzzle seriously questioned traditional explanations for financial crises (based on current account and fiscal deficits) and led analysts to focus on the intrinsic behavior of capital markets. Thus, it was argued that prevailing rules for capital market transactions may have been responsible for the spread of shocks from one country to other regions (Calvo, 1999). ${ }^{4}$

\footnotetext{
${ }^{4}$ As the argument goes, to the extent that there exist large fixed costs (relative to the size of projects) in obtaining information about a particular country, resulting economies of scale lead to the formation of clusters of specialists, or informed investors, who lead capital markets. These investors leverage their portfolios to finance their investments and are subject to margin calls in the event of a fall in the price of assets placed as collateral. Remaining investors, the uninformed, observe transactions made by informed investors, but are subject to a signal-extraction problem, given that they must figure out whether sales of the informed are motivated by lower returns on projects or by the informed facing margin calls. As long as the variance of returns to projects is sufficiently high relative to the variance of margin calls, uninformed investors may easily interpret massive asset sales as an indication of lower returns and decide to get rid of their holdings as well, even though the cause for informed investors' sales was indeed due to margin calls.
} 
In Figure 1, spreads measured by the EMBI+ index show a dramatic increase following the Russian crisis. Although they have since decreased, spreads exhibit a substantial gap compared to pre-crisis levels, exceeding 250 basis points for $2001 .^{5}$ This gap was much higher for 1999 and 2000 (over 700 basis points and 300 basis points, respectively, see Table 1).

Latin American markets were not the only ones hit by the higher cost of capital. For most EMs higher interest rates were accompanied by a large reduction in capital inflows. Figure 2 and Table 2 show that for the seven biggest Latin American economies the decline was sharp, particularly for portfolio flows, mimicking the sharp interest rate hike. The fact that the root of this phenomenon lied in Russia's crisis indicates that the capital-inflow slowdown contained a large unexpected component. "Large and highly unexpected" are the two defining characteristics of what the literature calls Sudden Stop (see Calvo and Reinhart, 2000). New information that a standstill in the capital account can materialize for rather exogenous reasons (and for a whole region) such as the Russian crisis, generating drastic effects on government sustainability (either because of debt revaluation effects or the emergence of contingent liabilities), may reduce the appetite for holding assets of countries that may be subject to big swings in the RER and are highly dollarized in their liabilities. Thus, this realization could bring the capital account to a lengthy standstill.

\footnotetext{
${ }^{5}$ We compare the lowest 1998 pre-crisis spread level to yearly averages of the spread measure in following years.
} 


\section{Figure 1}

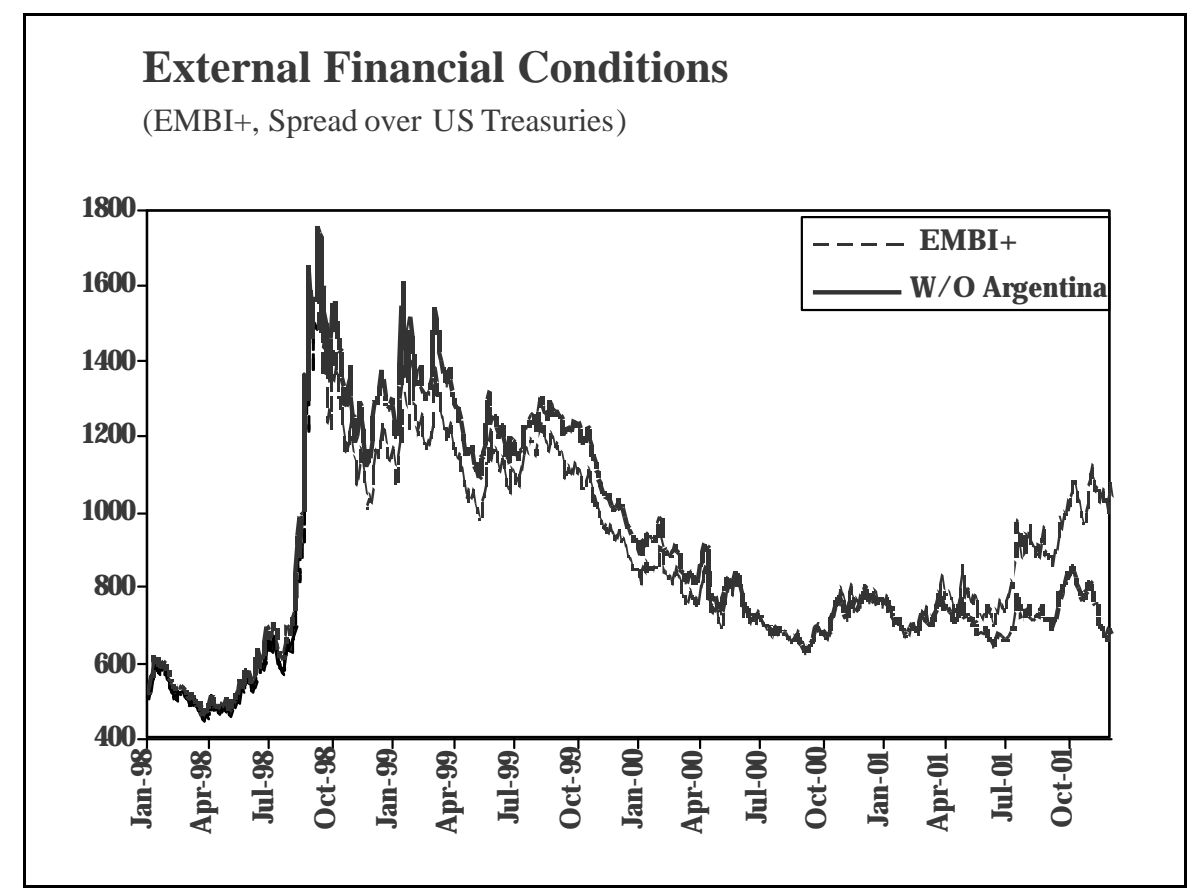

Source: JP Morgan Chase.

\section{Table 1}

Difference in Bond Spreads with Minimum Pre-Crisis Levels

\begin{tabular}{cccc}
\hline & $\mathbf{1 9 9 9}$ & $\mathbf{2 0 0 0}$ & $\mathbf{2 0 0 1}$ \\
\hline EMBI + & 666 & 307 & 393 \\
EMBI + w/ o Argentina & 757 & 315 & 259 \\
\hline \hline
\end{tabular}

Source: JP Morgan Chase. Note: Values are yearly averages. 
Figure 2

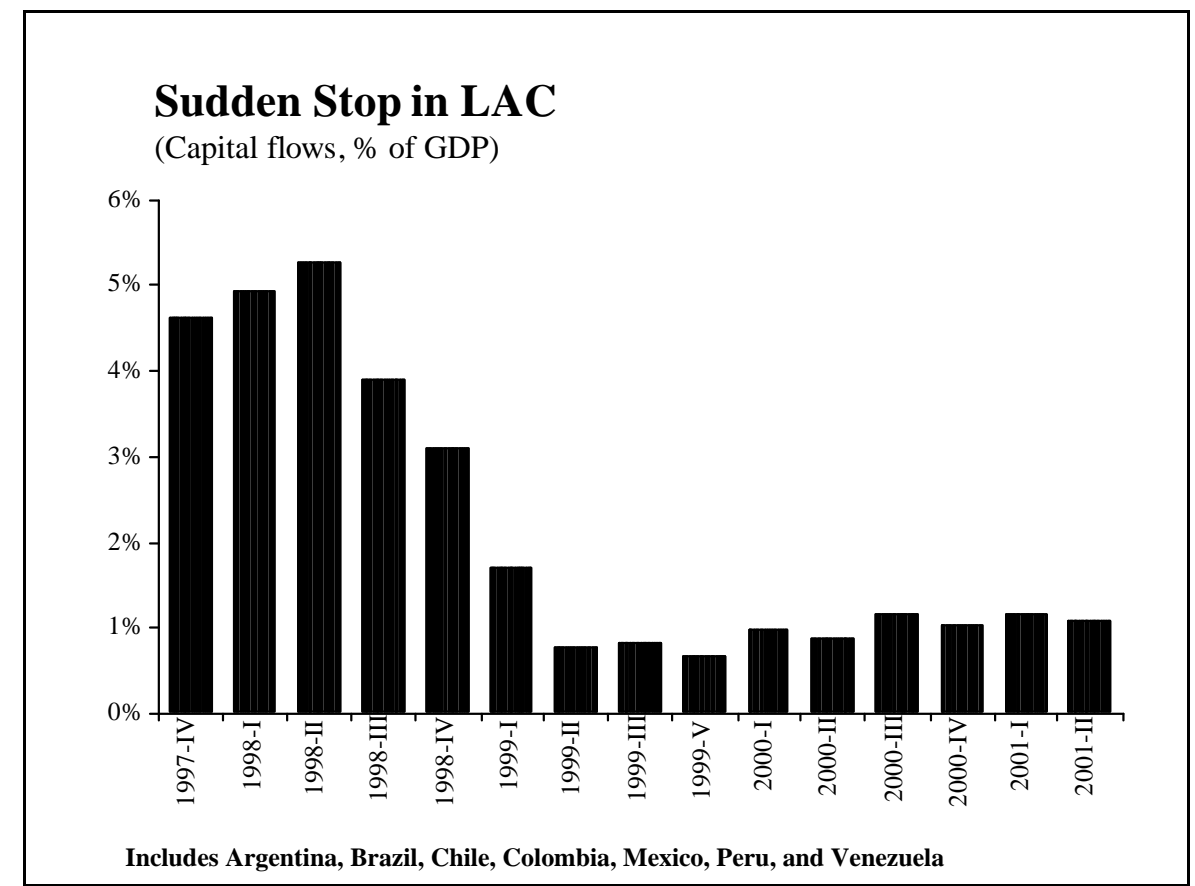

Source: Corresponding Central Banks.

Table 2

Capital Flows, \% of GDP

\begin{tabular}{lccc}
\hline & 1998.II & 2001.III & Reversal \\
\hline Capital Flows & 5.6 & 1.6 & -4.0 \\
N on-FD I Capital Flows & 2.0 & -0.9 & -2.9 \\
FD I & 3.6 & 2.5 & -1.1 \\
\hline \hline
\end{tabular}

Note: Includes Argentina, Brazil, Chile, Colombia, Mexico, Peru, and Venezuela. Source: Corresponding Central Banks.

Sudden Stops usually lead to a significant cut in current account deficits. Starting in the fourth quarter of 1998, key Latin American countries showed a steady decline in their current account deficits, which eventually reached a zero balance by the end of 
$2000{ }^{6}$ This adjustment of the current account was on average equivalent to 5 percentage points of GDP for the seven biggest Latin American economies (see Figure 3).

Figure 3

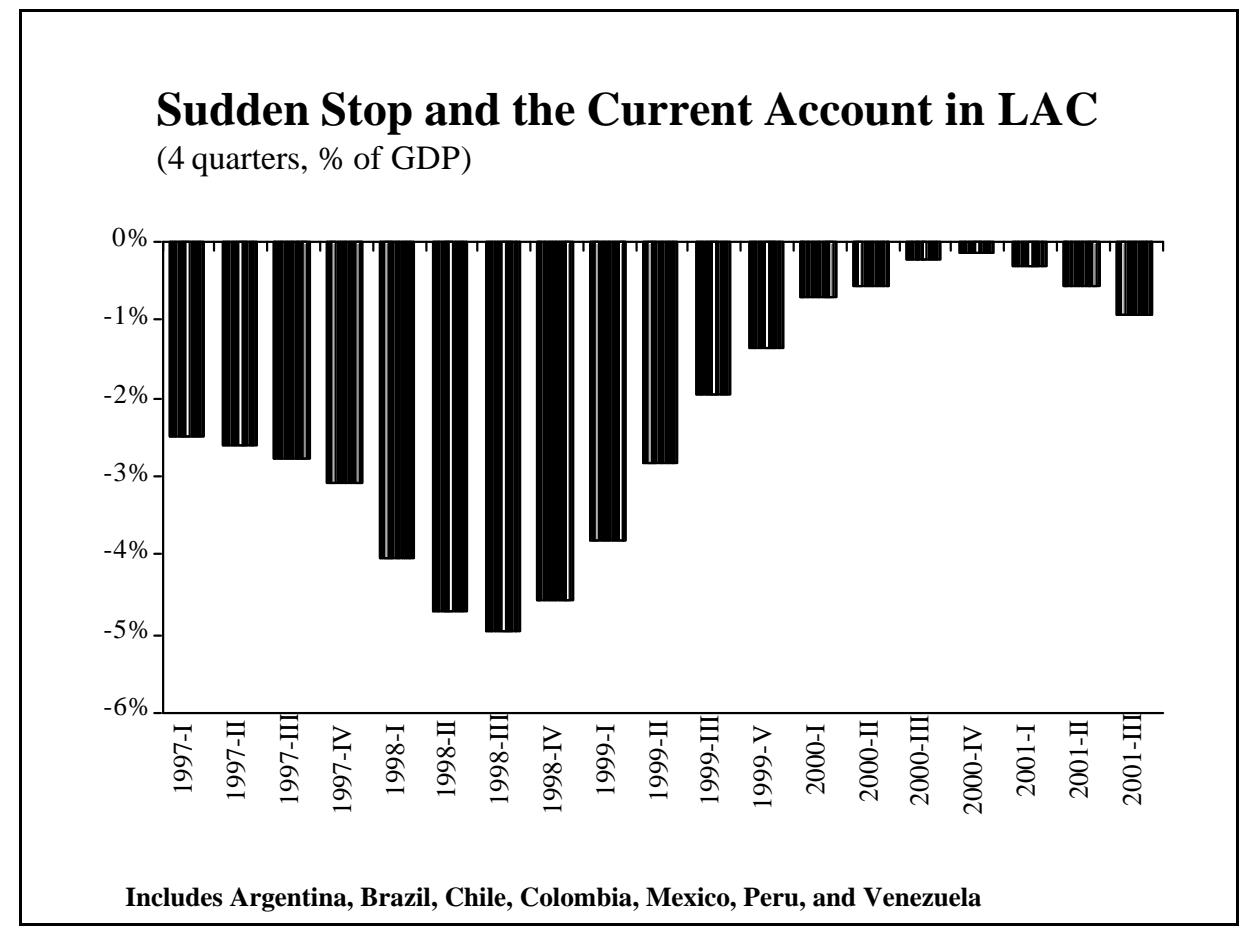

Source: Corresponding Central Banks.

\section{Sudden Stops and Real Exchange Rate Adjustment}

So far we have made a case for the large external component accounting for the observed fall in capital inflows. But what are the consequences of this event in terms of RER behavior and debt sustainability analysis? Two key elements in this discussion are

\footnotetext{
${ }^{6}$ Although FDI flows fell on average in the aftermath of the Russian crisis, they did increase significantly in Brazil, where FDI flows rose 80 percent in dollar terms from the second quarter of 1998 to the second quarter of 2001. We follow up on this fact because it may be an important element behind the resumption of capital flows to Brazil. A possible explanation is that higher interest rates led to sharp declines in domestic collateral, adding to the perception that this asset class was more risky than expected. Thus, domestic firms found it more difficult to finance the current operations and expansion plans, further
} 
the unexpected component of the Sudden Stop and its duration. It is clear that expectations prevailing before the Russian crisis are unlikely to have factored in the widespread effects on EMs that followed, so the unexpected element required for a Sudden Stop is met. A different question is whether this shock was perceived as temporary or highly persistent, which is quite relevant from a policy perspective. With the benefit of hindsight it is easy to argue that the shock had a large permanent component, since the stalling in capital inflows has lasted more than three years now. But it is not clear that it was perceived as such from the very beginning (this is an important point that we will revisit when we discuss Argentina in greater detail). Indeed, investors and policymakers had witnessed a quick recovery of capital flows following the Mexican (Tequila) crisis in 1995, which could have led them to expect a similar quick recovery after the Russian collapse. But things turned out differently. Figure 4 shows that two years after the Mexican crisis there was more than a complete recovery of capital flows, whereas there has been no recovery in capital flows to the region since 1998 following the Russian crisis. 


\section{Figure 4}

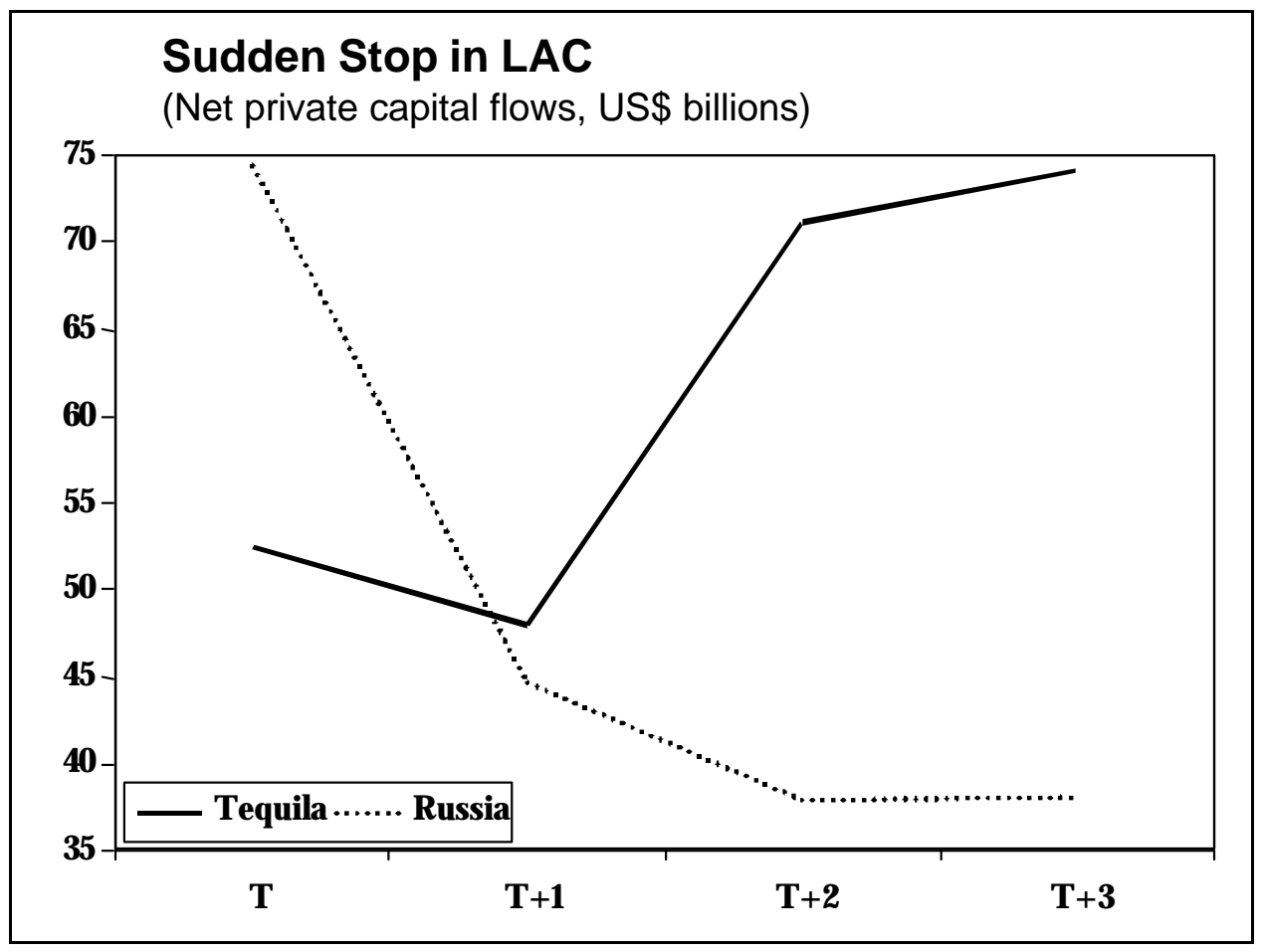

Note: "LAC" refers to Western Hemisphere countries, according to IMF definition.. "T" denotes the year of occurrence of the crisis. Source:World Economic O utlook (IMF), D ecember 2001.

Sudden stops are also typically accompanied by large contractions in international reserves and declines in the relative price of non-tradables with respect to tradables (i.e., real currency depreciation). By way of illustration, consider the case of a small open economy that experiences a current account deficit before a Sudden Stop takes place. By definition:

$$
C A D=A^{*}+S^{*}-Y^{*}
$$

where $C A D$ is the current account deficit, $A^{*}$ is absorption of tradable goods, $S^{*}$ represents net non-factor payments to foreigners, and $Y^{*}$ is the supply of tradable goods. If financing of the current account deficit is stopped, the full amount of that imbalance 
needs to be cut. Table 3 shows that current account adjustment can be sharp. Indeed, it is not uncommon to see an abrupt adjustment towards current account balance within a year following the Sudden Stop.

Table 3

\section{Current Account Balance, US\$ billions}

\begin{tabular}{cccccc}
\hline \multicolumn{7}{c}{ ARG } & BRA & CHL & COL & ECU \\
\hline 1998 & -14.5 & -33.4 & -4.1 & -5.2 & -2.2 \\
1999 & -11.9 & -25.4 & -0.1 & 0.2 & 0.9 \\
2000 & -8.9 & -24.6 & -1.0 & 0.3 & 0.7 \\
2001 & -5.6 & -23.2 & -0.9 & -2.1 & -0.8 \\
\hline \hline \multicolumn{7}{c}{ Current Account Change, \% of 1998 Imports } \\
\hline 1999 vs 1998 & ARG & BRA & CH L & COL & ECU \\
\hline 2001 vs 1998 & 21.1 & 10.6 & 18.8 & 31.3 & 49.0 \\
\hline \hline
\end{tabular}

Source: World Economic Outlook (IMF), April 2002.

A measure of the percentage fall in the absorption of tradable goods needed to restore equilibrium is given by:

$$
\eta=C A D / A^{*}=1-\omega
$$

where $\omega$ is a measure of the un-leveraged absorption of tradable goods, defined as:

$$
\omega=\left(Y^{*}-S^{*}\right) / A^{*} .
$$

Notice that this measure captures the share of absorption of tradable goods that is financed by the domestic supply of tradable goods. ${ }^{7}$ The lower this value, the higher will be the share of absorption of tradables financed from abroad. In other words, relatively closed economies with a small supply of tradable goods running a current account deficit

\footnotetext{
${ }^{7}$ Net of non-factor payments.
} 
will be highly leveraged. As we will see later, this is an important consideration regarding RER behavior after a sudden stop in capital flows.

In order to obtain an estimate for $\eta$ that can be used for cross-country comparisons, we proxy $A^{*}$ by imports. We use the observed current account adjustment for different periods, taken as a share of imports at the time of the crisis, in order to illustrate the observed percentage fall in absorption of tradable goods that was required to accommodate the change in the current account. Results are shown in Table 3 for 1999 and 2001. Countries like Chile, Colombia, and Ecuador, where the percentage fall ranged anywhere from 18.8 to 49 percent, experienced a quick and substantial adjustment in absorption of tradable goods by 1999. Adjustment in Brazil and Argentina has taken longer, a phenomenon that we will analyze in more detail later.

Having shown that the percentage fall of tradable goods absorption can be substantial after a Sudden Stop, we now consider effects on non-tradable goods. A common assumption in the literature is that preferences are homothetic, implying that the income expansion path of tradable vis-a-vis non-tradable goods is linear. Under this assumption, for a given RER, consumption of non-tradable goods is therefore proportional to that of tradable goods. ${ }^{8}$ As a result, a decline in demand for tradable goods of size $\eta$ must be matched by a proportional fall of equal size in the demand for non-tradable goods. Now consider the effects of this fall in demand on the RER. Given that the price of tradable goods is determined from abroad, all we need to take into account is the behavior of the non-tradable goods market. Define demand for nontradables as: 


$$
h=a-\chi p,
$$

where $h$ is (the log of) demand for non-tradable goods, $p$ is (the log of) the relative price of non-tradable to tradable goods, i.e., the inverse of the RER, $\chi$ is a parameter, and $a$ captures the income effect. Then, for a given RER, the fall in demand following a Sudden Stop is simply:

$$
d a=\eta=1-\omega
$$

Assuming, for simplicity, that the supply of non-tradable goods is fixed (so that $d h=0$ ), then the required percentage change in the real exchange, after differentiation of (4), is given by:

$$
-d p=(1-\omega) / \chi
$$

That is to say, the higher is the leveraged absorption of tradables, i.e. the lower is $\omega$, the higher the impact on the RER needed to restore equilibrium after a Sudden Stop. The intuition for this result is that, in the short run, the ability to generate purchasing power in terms of tradables is exports minus debt service. Thus, a Sudden Stop that requires a larger proportional sacrifice in absorption in terms of tradables, the smaller is $\omega$. Another element that affects our measure of absorption leverage is non-factor payments $\left(S^{*}\right)$, typically composed of interest payments, which implicitly captures indebtedness levels. High external indebtedness therefore reduces available resources to finance absorption of tradable goods, requiring greater RER realignment following the elimination of the current account deficit. Given these characteristics, $\omega$ is a good summary statistic to measure the impact on RER realignment. A further simplifying assumption we make is

\footnotetext{
${ }^{8}$ In what follows we abstract from investment. This is indeed a major omission, which is, however, likely to be less misleading in a steady state context such as the present one. Catena and Talvi, 2001, reach similar results in terms of a full-fledged dynamic model.
} 
that the supply of tradable goods can be measured by exports whereas, as earlier noted, imports serve as a proxy for absorption of tradables. ${ }^{9}$ Table 4 contains a list of Latin American EMs ranked by this measure in 1998. Chile clearly leads the ranking in terms of un-leveraged absorption. Argentina, although not the lowest ranked in the group, stands 15 percentage points below Chile, indicating that it would need greater RER realignment following a Sudden Stop.

\section{Table 4}

\begin{tabular}{ccccc}
\multicolumn{6}{l}{ Un-leveraged Absorption Coefficient $(\omega)$} \\
\hline BRA & ARG & ECU & COL & CHL \\
\hline \hline 0.56 & 0.66 & 0.66 & 0.70 & 0.81 \\
\hline \hline
\end{tabular}

Source: World Economic O utlook (IMF), and own estimates. Note: Values are given for 1998.

Another key element in determining the size of the required change in the RER is given by the price elasticity of the demand for home goods, $\chi$. Estimates for developing countries are typically much lower than those for industrial countries, implying that Sudden Stops can be much more devastating for EMs. Thus, not only are Sudden Stops a much more common feature of developing countries (see Calvo and Reinhart, 2000), but their effects can be more dangerous as well. Actually, the higher vulnerability of EMs to Sudden Stops could partly explain their higher recurrence.

Given this framework, we next ask what should be the size of RER realignment following a Sudden Stop that requires a full adjustment of the current account deficit, using 1998 as a starting point. To compute this, we make use of equation (6), taking a value of $\chi=0.4$ (the lowest point estimate in the literature). Given that we measure the

\footnotetext{
${ }^{9}$ A scenario that is makes sense in the short run.
} 
RER as the inverse of (antilog of) $p$, the rate of depreciation is $-d p$. Obviously, these figures should not be taken at face value, but as a way of ranking the effects of a Sudden Stop across countries. ${ }^{10}$ Table 5 shows the results. As it stands, this exercise indicates that Argentina would have needed to depreciate its RER by 46 percent in order to bring down its current account to zero, whereas Chile, for example would only have needed to depreciate its RER by 32 percent. This means that Argentina would have needed to depreciate its RER about 43 percent more than Chile in order to close the current account gap.

\section{Table 5}

\section{Required \% Change in Equilibrium RER}

\begin{tabular}{ccccc}
\hline BRA & ARG & ECU & COL & CH L \\
\hline 52.5 & 46.2 & 46.1 & 43.0 & 32.4 \\
\hline \hline
\end{tabular}

Source: World Economic Outlook (IMF), and own estimates. Note: Values are given for 1998.

Moreover, since the Russian crisis, between 1998 and 2001Chile depreciated its currency vis-à-vis the dollar by about 45 percent in real terms, and closed a current account gap of almost 19 percent of imports. Chile's current account deficit was equivalent to 6 percent of GDP in 1998 and fell to zero in 1999. In this respect, it would look like Chile's adjustment was larger than that of Argentina, whose current account deficit fell from 4.9 percent of GDP in 1998 to 2.4 percent of GDP in 2001. However, if Argentina's reduction in the current account gap is measured as a share of imports (the relevant measure from our perspective), the reduction was also 19 percent, similar to the adjustment observed in Chile. According to our model, Argentina's depreciation should

\footnotetext{
${ }^{10}$ Here we have made several strong assumptions, such as that the supply of both tradable and non-tradable goods are constant, and that the price elasticity of demand of non-tradables is low and the same across
} 
have been at least as large as that of Chile (45 percent), clearly indicating that the depreciation of the RER that effectively took place in Argentina (around 14 percent) was far from sufficient given the underlying adjustment in the current account. ${ }^{11}$ The slow adjustment of RER observed in Argentina can be explained by the combination of a fixed exchange rate and price stickiness (a relevant feature given the weight of public wages and public utility fees in price behavior), which retarded the adjustment of the RER.

\section{Debt Valuation and Fiscal Sustainability}

We now turn our attention to the effects of RER depreciation on fiscal sustainability. It is not uncommon to find countries where public sector debt is largely denominated in terms of tradables (see Table 6) and government revenue comes to a large extent from non-tradable activities. This introduces a currency mismatch in the public sector balance sheet, which makes any sustainability analysis highly susceptible to RER swings.

Consider the typical sustainability calculation, where the size of the primary surplus necessary to keep a constant ratio of debt to GDP is computed, given a cost of funds, and a growth rate for the economy. Take the standard asset accumulation equation:

$$
b_{t+1}=b_{t} \frac{(1+r)}{(1+\theta)}-s_{t},
$$

countries. Again, these figures do not attempt to match observed figures, but to illustrate the main transmission channels behind Sudden Stops.

${ }^{11} \mathrm{Had}$ Argentina reduced its current account balance to zero, the required adjustment should have been higher than that of Chile, as illustrated in Table 5. 
where $b$ is the debt to GDP ratio, $r$ is the real interest rate on debt, $\theta$ is the GDP growth rate, $s$ is the primary surplus as a share of GDP, and $t$ denotes time. To obtain a constant

debt to GDP ratio $(\bar{b})$, the budget surplus must satisfy, assuming constant $r$ and $\theta$ :

$$
s=\bar{b}\left[\frac{(1+r)}{(1+\theta)}-1\right] .
$$

Key to this analysis is the initial debt to GDP ratio $(\bar{b})$, which, in turn, depends on its denomination in terms of tradables and non-tradables. This ratio can be expressed as:

$$
\bar{b}=\frac{B+e B^{*}}{Y+e Y^{*}}
$$

where $e$ is the RER (defined as the price of tradables relative to non-tradables), $B$ is debt payable in terms of non-tradables, $B *$ is debt payable in terms of tradables, $Y$ is output of non-tradables, and $Y^{*}$ is output of tradables. Obviously, debt composition, as well as output composition, matter a great deal for sustainability analysis, because mismatches between debt and output composition can lead to substantial differences in valuation of the debt/GDP ratio following a real currency depreciation. For example, consider the limit case in which $b=e B * / Y$, where all valuation effects take place on debt only. This is the worst scenario in which RER depreciation hits fully on sustainability. Another case that is particularly relevant is that in which $\left(B / e B^{*}\right) /\left(Y / e Y^{*}\right)=1$, i.e., when the composition of debt and output is perfectly matched. When this condition holds, a change in the RER has no effect on fiscal sustainability. Table 6 shows how countries ranked in terms of mismatch at the time of the Russian crisis. ${ }^{12} \mathrm{~A}$ value of 1 would indicate a perfect match, and a value of zero would indicate the highest degree of 
mismatch. Clearly, the highest mismatch holds for Argentina. On the other side of the spectrum lies Chile, the best-matched economy, with a value of 0.45 .

\section{Table 6}

Public Sector Debt Mismatch Measure

\begin{tabular}{cccccc}
\hline & ARG & ECU & COL & BRA & CHL \\
\hline $\mathrm{B} / \mathrm{eB}^{*}$ & 0.08 & 0.02 & 0.59 & 1.76 & 1.30 \\
$\mathrm{Y} / \mathrm{eY}^{*}$ & 8.63 & 2.94 & 6.36 & 12.34 & 2.85 \\
$\left(\mathrm{~B} / \mathrm{e} \mathrm{B}^{*}\right) /\left(\mathrm{Y} / \mathrm{eY}{ }^{*}\right)$ & 0.01 & 0.01 & 0.09 & 0.14 & 0.45 \\
\hline \hline
\end{tabular}

Source: O wn estimates. Note: Values are given for 1998.

For comparison purposes, we consider the effects of a RER rise of 50 percent on debt valuation and fiscal sustainability for all the countries we selected, as of 1998 . The results are presented in Table $7^{13}$. We see clearly that under this scenario, Argentina, together with Ecuador, would be the hardest hit economy in terms of debt revaluation.

Just because of the relative price adjustment (holding the assumption that interest rates on public debt and GDP growth remain unchanged), Argentina's debt/GDP ratio would jump from 36.5 percent of GDP to 50.8 percent of GDP, an increase of nearly 40 percent on impact. Quite a different scenario plays out for Chile, where the debt revaluation effect is minimal: public sector debt as a share of GDP increases from 17.3 percent to 18.7 percent. It is interesting to see that in the case of Brazil, a 50 percent rise in the RER only affects the debt/GDP ratio by 14 percent. As we shall see later, in our view this was a key element, together with a substantial adjustment in the primary surplus, to

\footnotetext{
${ }^{12}$ We proxy output of tradable goods $\left(\mathrm{Y}^{*}\right)$ with exports. This measure is particularly relevant in the short run, although it could underestimate tradable output in the long run.

${ }^{13}$ Calculations were made assuming that debt is issued either in terms of tradable goods, or in terms of non-tradable goods. When debt is issued in domestic currency, the relevant price index for valuation purposes is the consumer price level, which typically includes a share of tradable goods in the basket it values. In this respect, real depreciation should affect the valuation of domestic-currency-denominated debt through the tradable component of the price level, making the effects of a RER rise larger than
} 
explain Brazil's success in controlling its fiscal position after the real currency depreciation it experienced in 1999.

\section{Table 7}

Fiscal Sustainability Under a 50\% RER Depreciation

\begin{tabular}{lccccc}
\hline & ARG & BRA & CHL & COL & ECU \\
\hline \hline (a) Base Exercise & & & & & \\
\hline O bserved Public D ebt (\% of G D P) & 36.5 & 51.0 & 17.3 & 28.4 & 81.0 \\
Real Interest Rate & 7.1 & 5.8 & 5.9 & 7.3 & 6.3 \\
Real G D P G rowth & 3.8 & 2.0 & 7.5 & 3.6 & 2.6 \\
O bserved Primary Surplus (\% of G D P) & 0.9 & 0.6 & 0.6 & -3.0 & -0.2 \\
& & & & & \\
& 1.2 & 1.9 & n.a. & 1.0 & 2.9 \\
i. Req. Primary Surplus (\% of G D P) & & & & & \\
(b) Change in Relative Prices & 50.0 & 50.0 & 50.0 & 50.0 & 50.0 \\
\hline Real E x change Rate D eprediation & 50.8 & 58.1 & 18.7 & 34.9 & 107.2 \\
Imputed Public D ebt (\% of G D P) & 7.1 & 5.8 & 5.9 & 7.3 & 6.3 \\
Real Interest Rate & 3.8 & 2.0 & 7.5 & 3.6 & 2.6 \\
Real G D P G rowth & & & & & \\
& 1.6 & 2.2 & n.a. & 1.2 & 3.9 \\
ii. Req. Primary Surplus (\% of G D P) & & & & & \\
& 14.3 & 7.1 & n.a. & 6.5 & 26.3 \\
N PV of ii - i (\% of G D P) & 28.2 & 12.2 & n.a. & 18.7 & 24.5 \\
Corresponding D ebt Reduction (\%) & 2.3 & 1.0 & n.a. & 1.3 & 4.5 \\
ii - i (\% of G overnment E x penditures) & & & & & \\
\hline \hline
\end{tabular}

Source: O wn estimates. Note: Values are given for 1998. n.a.: Not applicable given that the real interest rate is smaller than the growth of GDP, so sustainability is not a concern.

We also consider the effects on the required primary surplus following a rise in the RER. Making use of equations (8) and (9), we calculate the required primary surplus after revaluation of the debt/GDP ratio. ${ }^{14}$ It is important to note that these calculations implicitly assume that the shock is permanent. Had the shock been temporary, the effects on sustainability would be a lot less and, consequently, the need for adjustment would be 
smaller. But as it became apparent after the 1998 Russian crisis, this shock was highly persistent, implying that the adjustment in the RER and its effect on debt valuation was large as well. Of course, this was not clear at the time of the crisis, which led to underestimating the necessary fiscal adjustment.

Taking as a benchmark the case in which the RER depreciation is permanent, we estimate changes in the required primary surplus needed for sustainability. The biggest correction is for Ecuador (about 1 point of GDP). Argentina, for example, would require an adjustment of 0.4 points of GDP. In order to assess the significance of this adjustment, we estimate the net present value of the difference between the required primary surplus before and after the RER depreciation, which is equivalent to the change in debt before and after the shock, measured in percentage points of GDP. ${ }^{15}$ This figure would be equivalent to 14.3 points of GDP for Argentina, and as much as 26.3 points of GDP for Ecuador. Besides, these figures only represent changes in the required primary surplus, and, in most cases, countries had much lower observed primary surpluses than those required, meaning that the need for adjustment was much higher. In summary, once again we see that highly indebted, dollarized and closed economies are bad candidates to accommodate RER swings that will be fiscally sustainable.

Given that we have used exports as a proxy for tradable goods output in these calculations, we run the risk of overestimating the effects of RER depreciation because tradable goods output will typically be higher than exports. In order to assess the

\footnotetext{
${ }^{14}$ Assuming interest rates and GDP growth remain at initial levels, which underestimates the required primary surplus.

${ }^{15}$ This is computed as $(s *-s)(1+\theta) /(r-\theta)$, where $s^{*}$ is the required primary surplus after the rise in RER (real currency depreciation), $s$ is the required primary surplus before the rise in RER, $r$ is the real interest rate, and $\theta$ is the growth rate of the economy. This is obtained by solving (7) forward and taking the difference between the stream of flows valued at $s^{*}$ with respect to the stream of flows valued at $s$. In other words, it measures the change in debt (in percentage points of GDP) that corresponds to the permanent increase in the primary surplus.
} 
significance of this shortcut, we compare results against a more thorough measure of tradable output typically used for this calculation. This measure defines a category of output as tradable when imports plus exports of goods similar to those produced in that category exceeds output by more than 5 percent. This is performed for categories defined by the national accounting system at a one-digit level. Results are shown in Table $8 .{ }^{16}$

Table 8

Fiscal Sustainability under a 50\% Depreciation

\begin{tabular}{|c|c|c|c|c|c|}
\hline & ARG & BRA & CHL & $\mathrm{COL}$ & ECU \\
\hline \multicolumn{6}{|l|}{ (a) Base Exencise } \\
\hline$\overline{0 \text { bserved Public D ebt (\% of G D P) }}$ & 36.5 & & 17.3 & 28.4 & 81.0 \\
\hline Real Interest Rate & 7.1 & & 5.9 & 7.3 & 6.3 \\
\hline Real G D P G rowth & 3.8 & & 7.5 & 3.6 & 2.6 \\
\hline 0 bserved Primary Surplus (\% of G D P) & 0.9 & & 0.6 & -3.0 & -0.2 \\
\hline Req. Primary Surplus (\% of G D P) & 1.2 & & n.a. & 1.0 & 2.9 \\
\hline \multicolumn{6}{|l|}{ (b) Change in Relative Prices } \\
\hline Real E x change Rate D epreciation & 50.0 & & 50.0 & 50.0 & 50.0 \\
\hline Imputed Public D ebt (\% of G D P) & 47.2 & & 18.1 & 32.3 & 98.9 \\
\hline Real Interest Rate & 7.1 & & 5.9 & 7.3 & 6.3 \\
\hline Real G D P G rowth & 3.8 & & 7.5 & 3.6 & 2.6 \\
\hline Req. Primary Surplus (\% of G D P) & 1.5 & & n.a. & 1.1 & 3.6 \\
\hline NPV of $\mathrm{i}-\mathrm{ii}(\%$ of G D P) & 10.7 & & n.a. & 3.9 & 17.9 \\
\hline Corresponding D ebt Reduction (\%) & 22.7 & & n.a. & 12.1 & 18.1 \\
\hline i - ii ( $\%$ of $\mathrm{G}$ overnment $\mathrm{E}$ x penditures) & 1.7 & & n.a. & 0.8 & 3.1 \\
\hline
\end{tabular}

Source: O wn estimates. Note: Values are given for 1998.

As can be seen by comparing Table 8 with Table 7 , although there are some differences in debt to GDP ratios, the required primary surplus following an adjustment

\footnotetext{
${ }^{16}$ Results for Brazil could not be computed, given that national accounts data is not split according to standard classification.
} 
in relative prices does not change substantially, implying that our first approximation is indeed a good one to evaluate the effects of a Sudden Stop. ${ }^{17}$

Now that we have provided examples of the effects on the RER of closing the current account gap, and examples of debt revaluation for a given depreciation of the RER, we put both pieces together for the case of Argentina, and analyze the effects of a sudden stop in capital inflows in 1998 (results are summarized in Table 9). In our example, following a Sudden Stop, Argentina's RER would have to rise by about 46 percent. Had this depreciation occurred, the country would have displayed a debt/GDP ratio of 49.7 percent, a considerably larger value than that observed in 1998 (which was 36.5 percent of GDP). Under favorable growth and interest rate assumptions, ${ }^{18}$ the permanent primary surplus needed to sustain the new (and higher) debt/GDP ratio would have been equivalent to 1.6 points of GDP, 0.7 percentage points of GDP higher than the observed figure $(0.9 \%$ of GDP).

The above analysis only considers valuation effects, but Table 9 also examines two other factors associated with the Sudden Stop: interest rates and economic growth. On the one hand, if our hypothesis that the Russian crisis changed investors' perceptions about the risk associated with EM bonds is correct, then interest rates are likely to rise. On the other hand, the fact that GDP growth rates fell all over Latin America may have increased expectations of much lower growth than originally expected.

\footnotetext{
17 Even more thorough measures that split national accounts data at two or more digit levels may yield different results, but that information was not available for all countries in our sample, so we rely on calculations at a one digit level only.

${ }^{18}$ The growth rate used for this exercise is the geometric average of the previous 10 years. Interest rates are average rates on public debt prevailing in 1998. Both measures do not account for the fact that following a sudden stop in capital flows interest rates typically increase and growth prospects decline.
} 


\section{Table 9}

Fiscal Sustainability in Argentina Under Alternative Scenarios in 1998

\begin{tabular}{|c|c|c|c|c|c|}
\hline & $\begin{array}{l}\text { Debt to GDP } \\
\text { Ratio (\%) } \\
\end{array}$ & $\begin{array}{l}\text { i.Adjustment in } \\
\text { Prim. Surplus / a }\end{array}$ & $\begin{array}{l}\text { NPV of } i . \\
\text { (\% of GDP) }\end{array}$ & $\begin{array}{l}\text { i. (\% of Gov. } \\
\text { Expenditures) }\end{array}$ & $\begin{array}{c}\text { Debt } \\
\text { Reduction (\%) }\end{array}$ \\
\hline (a): Baseline / b & 36.5 & 0.3 & 9.3 & 1.5 & 25.6 \\
\hline $\begin{array}{l}\text { (b): C hange in Relative Prioes to close current } \\
\text { acoount deficit (RE R depreciation of } 46.2 \% \text { ) }\end{array}$ & 49.7 & 0.7 & 22.6 & 3.6 & 45.4 \\
\hline $\begin{array}{l}\text { (c): (b) }+200 \text { BPS Increase in Real Interest } \\
\text { Rate }\end{array}$ & 49.7 & 1.7 & 32.8 & 8.3 & 66.0 \\
\hline (d): (c) + 1\% Reduction in Real G D P G rowth & 49.7 & 2.2 & 35.6 & 10.8 & 71.7 \\
\hline (e): (d) + Contingent L iabilities & 58.6 & 2.7 & 44.5 & 13.5 & 75.9 \\
\hline
\end{tabular}

Source: O wn estimates.

a/ The observed primary surplus for 1998 was 0.9 percent of GDP. b/ The baseline scenario assumes a long run rate of growth of $3,8 \%$ and a $7,1 \%$ real interest rate.

Re-computing our estimates under the assumption that interest rates remain 200 basis points higher than in 1998 (an increase similar to the observed increase in EMBI spreads in 2001 compared to pre-Russian crisis levels) and growth estimates fall by one percent, the primary surplus needed to achieve fiscal sustainability following a Sudden Stop, goes all the way to 3.1 percent of GDP, or about 2.2 percent of GDP above the observed value for 1998 (see Table 9). The needed adjustment is equivalent to 13.5 percent of total expenditures, a large figure from a political perspective. Alternatively, the size of debt reduction required for sustainability in the absence of a fiscal adjustment, exceeds 75 percent once we factor in all the different elements of a Sudden Stop that affect the fisc. From a credit risk perspective, this is also a large figure that helps us understand why under imperfect credibility on future primary surpluses, the ability to roll over the existing stock of debt was severely hampered after the Sudden Stop. It is worth

Thus, sustainability calculations are less demanding than those that would prevail had these additional effects been incorporated. We account for this later on. 
noticing that under the 1998 baseline scenario ${ }^{19}$ it is not evident that Argentina's fiscal position was out of control. Indeed, standard sustainability analysis indicates that the difference between the required and observed primary surplus was 0.3 percentage points of GDP at prevailing RER, growth and real interest rate levels (see Table 9).

Undoubtedly, Argentina was quite vulnerable to RER swings, but it was not clear before the Russian crisis that Argentina's fiscal position was out of hand in the absence of a Sudden Stop. ${ }^{20}$ This warns about the need to obtain risk-weighted measures of fiscal sustainability that account for the occurrence of events such as a Sudden Stop. This type of tool could prove beneficial to internalize the need for more conservative fiscal policy. This experience highlights two relevant aspects pertaining debt: both debt levels and indexation clauses are crucial in determining the effects of Sudden Stops on sustainability. High debt levels imply little room for cushioning valuation effects. Higher debt service, in turn, may imply higher RER swings. And dollarization (or indexation to the dollar) can trigger substantial valuation effects that may compromise solvency.

It is useful to contrast the Chilean and Argentine experiences in terms of sustainability. Chile was subject to a Sudden Stop that forced the country to bring the current account to almost a zero balance, an adjustment equivalent to 18.8 percent of imports. Yet, it fared much better in terms of fiscal sustainability. Chile differed from Argentina in two respects. First, as we already argued in the previous section, Chile required a smaller RER realignment given the country's openness and low indebtedness position. Second, recalling our exercise on the valuation effects of a rise of 50 percent in

\footnotetext{
${ }^{19}$ That is when we take the prevailing average interest rate, growth rate and RER instead of imputed postshock levels.
} 
the RER (close to Chile's effective depreciation of 45 percent) described in Table 7, it is clear that Chile's debt/GDP ratio remained almost unchanged. Chile's relatively high share of tradables in GDP, and relatively low ratio of debt in tradables to total debt, helped dampen the effect of the rise of the RER on sustainability. Thus, very little changed in terms of sustainability for Chile after the Sudden Stop. Moreover, the RER shift was successful in switching production to tradables (an effect that we do not consider in our model), thus compensating in part for the standstill in capital flows. Table 10 shows the change in exports relative to the change in the current account deficit observed one year and three years after the Russian crisis, as an indication of the contribution of exports in closing the current account gap. It clearly shows that Chile was highly successful in switching production to tradables, something that did not occur in Argentina, in part because the RER misalignment was providing little incentive to do so.

Table 10

Exports Change / Current Account Change, \%

\begin{tabular}{cccccc}
\hline \multicolumn{7}{c}{ ARG } & BRA & CH L & COL & ECU \\
\hline 1999 vs 1998 & -127.5 & -47.6 & 11.1 & 8.7 & 8.0 \\
2001 vs 1998 & -1.8 & 82.7 & 79.1 & 43.8 & 41.8 \\
\hline \hline \multicolumn{7}{c}{ Exports Change, \% } \\
\hline ARG & BRA & CH L & COL & ECU \\
\hline 1999 vs 1998 & -10.6 & -6.5 & 2.4 & 3.5 & 5.0 \\
2001 vs 1998 & -0.5 & 14.3 & 13.4 & 10.2 & 11.3 \\
\hline \hline
\end{tabular}

Source: World Economic O utlook (IMF), April 2002.

Another interesting case to contrast with Argentina is that of Brazil. Why was the rise in the RER in Brazil successful? Three factors contribute to its explanation. First, by 1999 , the country's adjustment of the current account was equivalent to only 10.6 percent of imports, far below the 44.2 percent that would have occurred had the current

${ }^{20}$ This assertion is made without considering the possibility that the RER was appreciated by 1998 . 
account deficit been completely eliminated. So what made Brazil avoid a bigger adjustment? Contrary to the experience of other countries, the Sudden Stop in Brazil was short-lived and quickly compensated by FDI flows, which increased 80 percent in dollar terms between the second quarter of 1998 and the second quarter of 2001. According to our view, this prevented an even larger currency meltdown. ${ }^{21}$ Second, Brazil's level of indebtedness was quite high in 1998 (51 percent of GDP) and a sustainability analysis along the lines presented here would have shown that large fiscal adjustment was also needed. After the 1999 crisis and in contrast to Argentina, Brazil responded with a severe fiscal adjustment, which increased its primary balance considerably by $3.5 \%$ points of GDP in 1999. This adjustment proved to be politically feasible and long lasting, two factors that are crucial in explaining Brazil's success in weathering the Sudden Stop, something that was unattainable by Argentina. And third, a crucial difference with Argentina is that by 1998, although Brazil's public debt was higher as a share of GDP than in Argentina, it was only partially dollarized, as Table 6 shows. Since the level of dollarization was also relatively low in the private sector, contingent liabilities were kept in check, an issue we will discuss further in the next section. Therefore, revaluation effects of real currency (i.e., a rise in RER) over the public debt/GDP ratio were not substantial.

\footnotetext{
${ }^{21}$ One can only conjecture that to the extent that FDI flows were due to opportunities facing foreign investors given the low valuation of Brazilian firms after the devaluation of the Real (a one time shot), Brazil should be ready for additional fiscal adjustment in case FDI flows do not proceed at the previously observed pace.
} 


\section{Real Exchange Rate Adjustment and Contingent Liabilities}

So far we have not discussed another issue that further raises the hurdle for any type of sustainability analysis following a Sudden Stop, namely, the existence of contingent liabilities of the public sector, originated in the corporate and banking sectors. Here the financial system becomes an element of extraordinary importance. It is not uncommon, as was the case of Argentina recently (and cases like Thailand, for example, in previous crises), to find that commercial bank loans are heavily dollarized, whereas a large proportion of bank debtors obtain income from non-tradable activities. This currency mismatch between debtors' revenues and liabilities can easily lead to financial distress following large swings in the RER, as balance sheets deteriorate dramatically with the increased value of loans, which usually render these sectors bankrupt. To the extent that expectations concur that the public sector is willing to bail out banks and/or the corporate sector in the event of a crisis (another common feature of recent crises), then this bailout ought to be added to the sustainability analysis of the fisc. The combination of big RER swings, highly dollarized public debt, and the materialization of contingent liabilities of this sort can send debt/GDP ratios to skyrocketing levels, rendering public sector accounts bankrupt. Argentina suffered from all of these. Rough estimates of the bank bailout yield anywhere between US\$7bn and US\$13bn, and this excludes previous rediscounts and repos placed with public banks to finance their deposit losses equivalent to about US\$6bn. Putting it all together yields an additional burden of US\$13-19bn, which raises the debt/GDP ratio after the shock to anywhere between 55.8 and 58.6 percent, almost two thirds higher than the pre-crisis 1998 measure! 
Obviously, public debt surges of this magnitude are the prelude to a wealth redistribution conflict given the size of the required adjustment. Once all elements triggered by the Sudden Stop are factored in, ${ }^{22}$ the primary balance needed to regain sustainability would have exceeded 3\% of GDP, a figure never attained by Argentina in its recent history (see Table 9). In order to achieve this, the government would have needed to come up with new sources of financing or a cut in expenditures. It is evident from our previous discussion that the corporate sector could not be considered a good candidate for taxation, given that it was facing the same balance sheet breakdown and credit crunch confronted by the government. Thus, abstracting from default, the government was left with basically two alternatives: taxing consumers or reducing expenditures via wage cuts. Both instruments were to some extent used by different ministers during the de la Rua administration, but they proved to be politically very tricky because both were mostly placing the burden over the shoulders of the middle class, de la Rua's main political constituency. Besides, these loosing groups in the wealth redistribution game eagerly challenged the implicit decision of the government to leave external creditors unscathed. The redistribution conflict gave rise to a war of attrition in which decisions were delayed, deepening the extent of the crisis and the credibility of the public sector in terms of its ability to generate fiscal surpluses of the magnitude needed to regain sustainability. This, of course, closed any remaining open doors to government financing from abroad, thus making it clearer that the solution to this conundrum would most likely involve debt restructuring, something that lay at the heart of the bank run experienced in 2001. Most bank assets comprised loans to the private sector (most of

\footnotetext{
22 That is, valuation effects, interest rate increases, growth slowdown and the emergence of contingent liabilities.
} 
them exhibiting currency mismatch) as well as government bonds. Both stocks would be severely hit at the time of the crisis. This realization precipitated a run by depositors in order to avoid the expected confiscation of their deposits.

In summary, when judging sustainability by taking into account the valuation impact of a Sudden Stop and the cost of a bail out of the corporate sector on the balance sheet of the government, it would become apparent that by late 1999 Argentina had acquired a large debt problem as summarized in Table 9. To "fix" this problem would have required very large cuts in government expenditures at a time when the fixed peg to the dollar left Argentina without a valuable instrument, i.e., inflation, to engineer large government expenditure reductions which are politically very costly to implement in an explicit way.

Once we take into account the standards set by the new equilibrium RER, the de la Rua administration was facing an uphill battle in order to restore creditworthiness. The fair question to be asked is whether adjustments of such magnitude would have been feasible with standard fiscal policy instruments. Under lack of credibility, Argentina was definitely facing a stock problem, which can hardly be resolved with a tool such as the public sector deficit, which represents a flow, unless it is expected to be long-lasting. This was a tall order given the weak political structure underlying de la Rua's administration. Indeed, at this stage it would have been extremely difficult for any government to search for a solution that did not involve some form of debt restructuring.

Before concluding this section, let us revisit the issue of the expected duration of the Sudden Stop and expectations about Argentina's lack of fiscal sustainability. As it has already been argued, all sustainability calculations presented here were made under 
the assumption that the shock was permanent, but it is not clear that the shock was initially perceived as such by capital markets. Figure 5 shows Argentina's public bonds' spread measured by the EMBI index relative to the EMBI average for emerging markets. The fact that for the period starting with the Russian crisis through early August of 2000, Argentina's relative spread was lower than the average spread, indicates that the market had not yet declared Argentina insolvent.

Figure 5

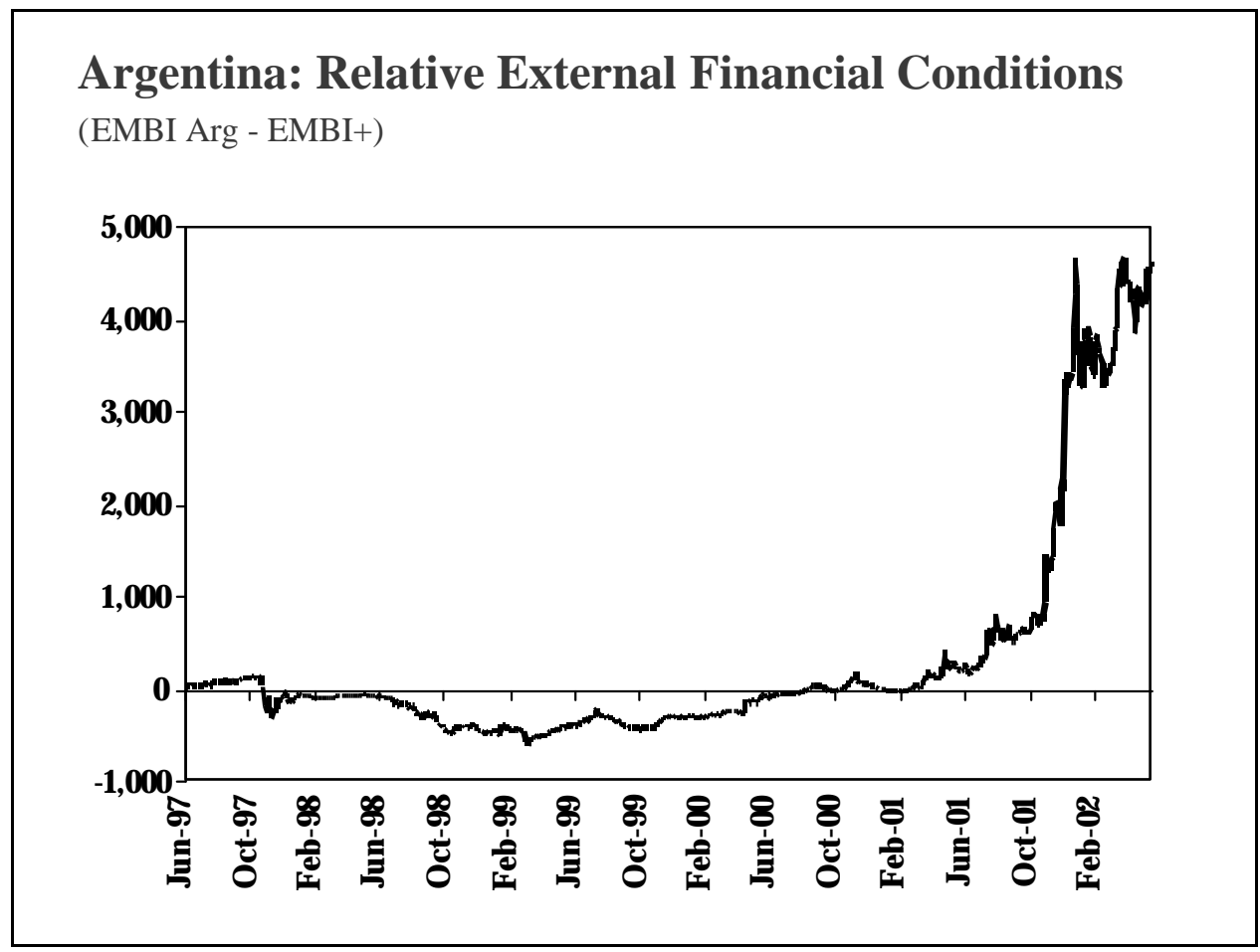

Source: Bloomberg.

Although private capital flows had already dried up by early 1999 (see Figure 6), two factors may have contributed to avoiding bankruptcy expectations. First, it was not clear that the shock would be permanent (introducing uncertainty about the size of the required adjustment in relative prices), and therefore, it was not clear that Argentina's position would become unsustainable. But to the extent that investors updated 
expectations about the duration of the shock based on past and present behavior of capital flows, the observed persistence of the initial Sudden Stop deteriorated expectations about Argentina's fiscal solvency, thus contributing to the increase in spreads. Second, although lower output levels resulting from the private sudden stop in capital flows impacted directly on tax collection, putting additional strain on fiscal accounts, multilaterals provided financing to the public sector during this period. Had the shock been temporary, this additional financing would have been sufficient to cover the government deficit and avoid default since there would be no underlying sustainability problem. But as time went by and it became clear that capital inflows were not returning, real currency depreciation (i.e., a rise in RER) was unavoidable and sustainability was at stake.

Figure 6

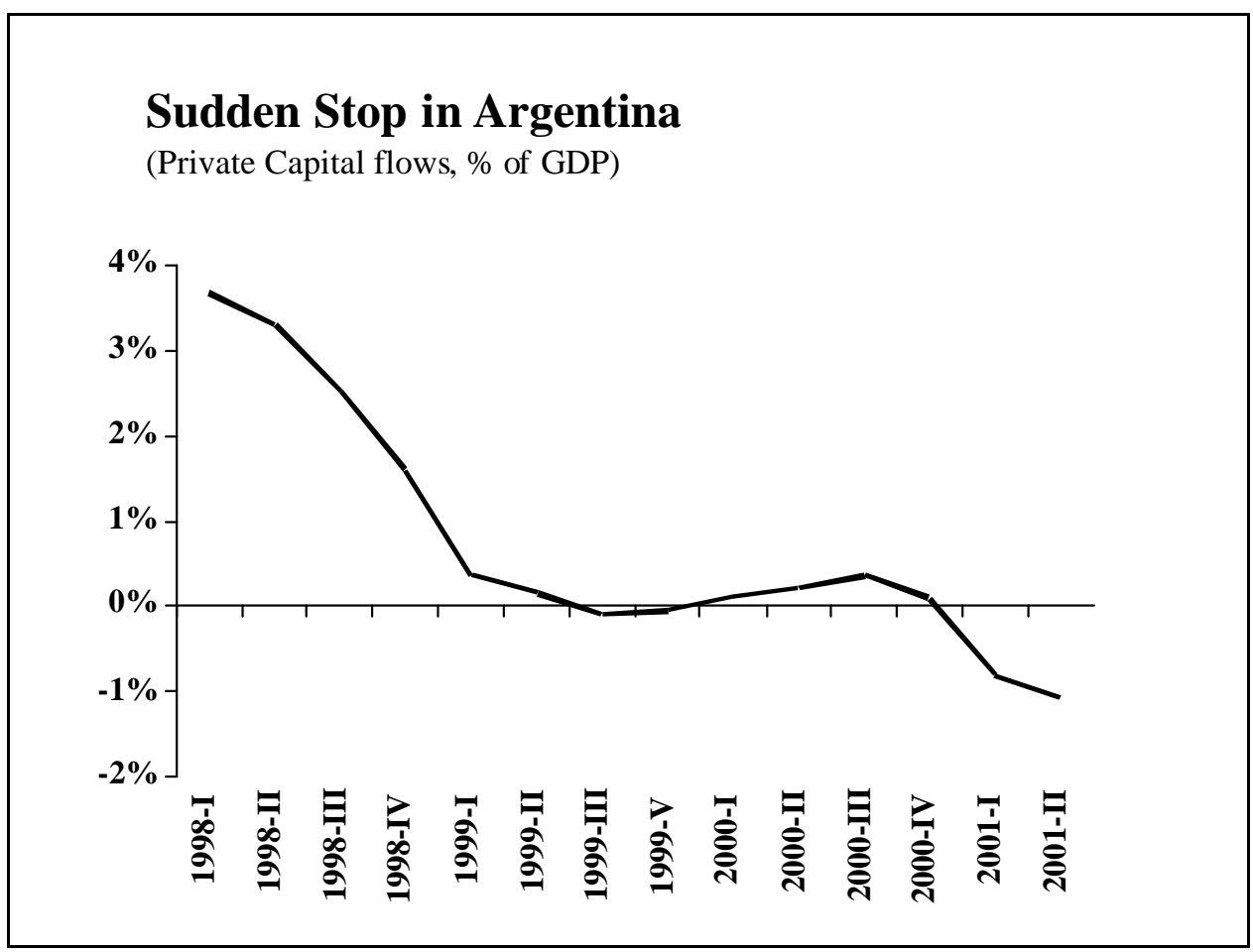

Source: Central Bank of Argentina (BCRA). 


\section{Nominal Exchange Rate Issues}

We now briefly turn to the implications of having kept a fixed exchange rate regime in place when the sudden stop in capital flows hit Argentina (requiring substantial changes in the RER), and contrast this against a scenario where the exchange rate is allowed to float. The Argentine experience shows that under certain conditions, fixed exchange rates can help to conceal fiscal disequilibrium. In particular, if prices are sticky, the RER may take time to reach its new equilibrium, revealing very little about the true magnitude of the necessary fiscal adjustment. The problem is that under those circumstances, it would be politically very hard to justify the need for a substantially larger fiscal retrenchment. This would be true even if we assume (unrealistically) that the International Monetary Fund and policymakers were aware of the yawning misalignment. The fact that the true magnitude of the fiscal adjustment was not evident may also be relevant in explaining the political turmoil that took place in 2000 in Argentina. Faced with the dilemma of deciding whether it was necessary or not to proceed with fiscal adjustment, the ruling alliance experienced substantial tension. This may very well have been the underlying force behind the resignation of several cabinet members and its implicit breakup following the vice-president's resignation. Even if sluggish RER adjustment was concealing the need for fiscal adjustment, one may ask whether other variables such as central bank reserves could have revealed that information. Under a fixed exchange rate regime, reserve loss would be a signal for adjustment. But this variable can be a very noisy signal. For example, to the extent that the crisis is anticipated, consumption will be higher before than after the crisis (see Calvo, 1986), and so will money holdings and reserves in a cash-in-advance model. Thus, reserves may 
actually conceal the need for adjustment. Also, to the extent that reserves are supported by multilateral loans, they may mask the needed corrections (for a discussion of reserves as noisy signals, see Talvi, 1997 and Calvo, 1998).

These considerations immediately raise the question: Would it have been very different had Argentina floated its exchange rate instead in January 2000? Leaving any initial overshooting aside, the floating rate may have revealed that Argentina was in the dumps. The de la Rua administration would have faced some of the same difficulties currently faced by Duhalde's administration, such as dealing with a banking system bailout. However, remedial measures may have been taken then, avoiding the costly financial engineering that was undertaken later in 2001. Moreover, the alliance was supported by a strong popular vote. This power endowment would have been instrumental in finding an expedient resolution to the crisis, something that the current administration would very much relish.

However, the above scenario is unrealistic. Authorities would likely have been reluctant to let the exchange rate go as far up as required to reach equilibrium RER. Be it because of high liability dollarization, high pass-through from the exchange rate to inflation, or lack of credibility, the authorities would likely have suffered from "fear of floating" (see Calvo and Reinhart, 2002). For these reasons, we conjecture that devaluation would have gone only half way. Thus, although the RER would have adjusted more rapidly at the beginning, interest rates would have exhibited a sharp increase. Surging interest rates are the result of incomplete devaluation and, thus, the expectation of more devaluation to come (peso problem). Higher future devaluation could bring about an Indian Summer in aggregate demand but, eventually, boom gives 
way to bust. The lower price of consumption today vis-à-vis the future may lead to an increase in aggregate spending, but inevitably this gives way to bust in the future as the wealth constraint binds. Therefore, it is unclear that a more flexible exchange rate system would have successfully cleared the air in 2000. Even if the nominal exchange rate had been allowed to float freely, results would not have been much different. Argentina's high vulnerability to big swings in the RER following a Sudden Stop and its detrimental effects on corporate balance sheets and fiscal sustainability were there to stay regardless of whether the exchange rate regime was fixed, or allowed to float.

On the other hand, it is clear that floating the exchange rate was indeed a solution to the problem of nominal wage inflexibility faced by the government in the last few months before the collapse of Convertibility, a key element in bringing down real expenditure levels through inflation. ${ }^{23}$ But this clear benefit in "facilitating" the fiscal adjustment would probably have been insufficient to compensate for the balance sheet breakdown caused by Liability Dollarization. As result, a debt restructuring process to resolve the dynamics set in motion by the Sudden Stop became inevitable.

\section{Lessons and Policy Issues}

We now take stock and use what we have learned to list a set of lessons/policies for Latin America that are derived from our analysis of vulnerability to Sudden Stops. An overview of the specific attempts made in Argentina to escape the crisis, and the reasons why we believe they failed, are left for the Appendix.

\footnotetext{
${ }^{23}$ A floating exchange rate regime is a solution to a fixed exchange rate regime facing serious difficulties, such as a Sudden Stop. But this does not necessarily point to floating exchange rates as a better regime, since the advantages of such a regime should be evaluated ex-ante.
} 
Argentina was extremely vulnerable to a sudden stop in capital inflows such as the one that followed the Russian crisis due to three characteristics: extremely closed to international trade $(C)$, highly indebted $(D)$, a high degree of de facto dollarization both in the public and private sector and, as a result, large financial currency mismatches $(M)$. For future reference we will call an economy with these characteristics a $C D M$ economy. Without any pretense of being exhaustive, in what follows we list the main policy lessons that logically emerge from our analysis:

1. $C D M$ economies are vulnerable to changes in international conditions that require an adjustment in the current account deficit since they may require correspondingly large increases in equilibrium RER.

2. In $C D M$ economies, large changes in the RER could generate deep financial distress in the corporate sector and/or turn a sustainable fiscal position into an unsustainable one, leading to financial problems for the public sector as well.

3. A banking crisis may be the inevitable corollary, either because banks are themselves exposed to RER changes and/or because they are exposed to the public sector through large holdings of public debt.

\section{Exchange Rate Policy}

4. $C D M$ economies are vulnerable, regardless of the exchange rate regime that is adopted. Sudden Stops are shocks to credit that generate real effects, with long-run outcomes that are independent of nominal exchange rate arrangements (although shortrun dynamics can vary substantially depending on nominal arrangements). 
5. Exchange rate flexibility could play a useful role if the $C, D$ or $M$ are dropped (as was the case of Chile). It may be particularly useful if nominal wage inflexibility in the public sector is an issue. Otherwise, however, exchange rate flexibility could give rise to non-transparent policies, which might do more harm than good. In the short run, the $C$ is hard to drop, and dropping $D$ or $M$ could be traumatic (as exemplified by Argentina's default and pesofication).

\section{Fiscal Policy}

6. Prima facie, in $C D M$ economies it is dangerous to have high levels of public indebtedness. Governments should decide on lower debt levels (based on their degree of openness and Liability Dollarization) that create the necessary space for the public sector to respond in times of crisis while securing sustainability.

7. Dealing with an unsustainable fiscal position involves wealth redistribution across sectors. The way and the speed at which that redistribution is made are crucial in determining how fast a crisis is resolved. Ideally, wealth redistribution should be contracted ex-ante. ${ }^{24}$

\section{Trade Policy}

8. Increasing trade openness (i.e., dropping the C) may be relevant not just because it reduces the size of RER swings after a Sudden Stop, but also because, from a financial perspective, a higher share of tradable sectors in output composition may reduce the risk of currency mismatches in private sector balance sheets. This effectively reduces the vulnerability of the banking sector following RER swings, as well as the size of potential bailouts that may worsen the fiscal position. Although the literature has focused on the

\footnotetext{
${ }^{24}$ For example, Brazil sold exchange rate insurance to private firms (and its cost was budgeted). This avoided a costly redistribution process by the time Brazil faced devaluation in 1999.
} 
benefits of openness for growth, the financial channels described above may be equally important.

\section{$\underline{\text { Debt Management Policy }}$}

9. Efforts should be made to create markets for the issuance of debt in domestic currency not indexed to the exchange rate (i.e., dropping M). ${ }^{25}$ Any debt contract that is contingent on RER fluctuations could be highly beneficial, not only because it may soften valuation effects, but because it specifies ex-ante the redistribution process generated by a Sudden Stop, thus avoiding the costly resolutions and the associated political turmoil. But this must be done in such a way that two common weaknesses are avoided: First, debt should be issued under terms that eliminate incentives to inflate it away through money creation (such as CPI indexing). Second, issuance should be made at sufficiently long maturity to avoid vulnerability to liquidity shocks. Typically, attempts to issue debt with these characteristics have not been successful. But a recurrent characteristic of these attempts has been the fact that issuance was made under domestic law instead of international law. Thus, there may be a significant difference in risk other than that associated with exchange rate risk, which may further complicate currency-matching strategies.

\footnotetext{
${ }^{25}$ Indeed, this is just one instrument to insulate the economy from the effects of external shocks. Other instruments, contingent on indicators of external shocks (such as main export commodity prices), could be just as beneficial. For more on this, see Caballero (2002).
} 


\section{References}

Caballero, R. (2002) “Coping with Chile's External Vulnerability: A Financial

Problem", [online paper] URL: http://web.mit.edu/caball/www/Chile_11Jan2002.pdf

Caballero, R., and A. Krishnamurthy (2003). “A 'Vertical' Analysis of Monetary Policy

in Emerging Markets", [online paper] URL:

http://web.mit.edu/caball/www/verticalaer.pdf

Calvo, G.A., (2002a) "Explaining Sudden Stop, Growth Collapse, and BOP Crisis: The

Case of Distortionary Output Taxes", [online paper] URL:

http://www.imf.org/external/pubs/ft/staffp/2002/00-00/pdf/calvo.pdf

Calvo, G.A., (2002b) “Globalization Hazard and Delayed Reform in Emerging Markets,"

Economia, Spring 2002, (2) 2.

Calvo, G.A, and C. Reinhart, (2002) "Fear of Floating," Quarterly Journal of Economics, (117) 2: 379-408.

Calvo, G.A., and C. Reinhart, (2000) "When Capital Flows come to Sudden Stop:

Consequences and Policy", in P.K. Kenen and A.K. Swoboda (Eds.) Reforming the

International Monetary and Financial System, International Monetary Fund: 175-201.

Calvo G.A., (1999) “Contagion in Emerging Markets: When Wall Street is a Carrier”,

[online paper] URL: http://www.bsos.umd.edu/econ/ciecrp8.pdf

Calvo, G.A., (1998) “Growth, Debt, and Economic Transformation: The Capital Flight

Problem", in F. Coricelli, M. Di Matteo and F. Hahn (eds.) New Theories in Growth and

Development, Palgrave Macmillan: 251-69.

Calvo, G.A., (1986) “Temporary Stabilization: Predetermined Exchange Rates”, Journal of Political Economy, (94) December:1319-1329. 
Catena, Marcelo, and Ernesto Talvi (2001), "Sudden Stops in a Dynamic General Equilibrium Model: an Application to Latin American Countries", mimeographed document.

Izquierdo, A., (1999) "Credit Constraints, and the Asymmetric Behavior of Output and Asset Prices under External Shocks", Ph.D. dissertation, University of Maryland.

Sturzenegger, F., and M. Tommasi, (1998) "The Political Economy of Reform”, Boston, MA: MIT Press.

Talvi, E., (1997) "Exchange Rate Based Stabilization with Endogenous Fiscal Response”, Journal of Development Economics, (54) October: 59-75 


\section{Appendix}

\section{Domestic Policies in Argentina under the Perspective of the Sudden Stop}

Here we will present, and briefly discuss policies that were pursued in Argentina prior to the fall of the Convertibility Program.

Fiscal Policy. From the previous discussion, it is clear that fiscal restraint introduced during end-1999/early-2000, although in the right direction, was not sufficient to cope with the sustainability demands raised by the new equilibrium RER and the expected bailout of the private sector, making it difficult for the government to sustain the higher levels of debt, thereby creating a stock problem. The Fund was not immune to this misunderstanding. Under the assumption that Argentina was facing a liquidity problem, the initial program agreed upon with the de la Rua administration was followed

by the blindaje. ${ }^{26}$ Fiscal policy was relaxed and the original program was buttressed by a larger package. This failed, as the program was now shooting in the wrong direction. This mistake in diagnosis could be key in understanding why there was a lack of consensus about the degree of fiscal adjustment needed to restore credibility. When the size of adjustment reaches the magnitude required by the Sudden Stop, it is easy to see why a heterogeneous political alliance can break up. This was exacerbated by the fact that economists did not offer a clear explanation to politicians about the reasons and urgency for adjustment, and particularly about the need to regain solvency if the capital flow standstill was ever to be reversed. This conceptual and political maelstrom was a clear source of uncertainty for the private sector about the future. In this respect, it is not surprising that investment projects were suspended, resulting in higher unemployment. 
An attempt to introduce a fiscal package in early 2001 by a new minister ${ }^{27}$ (which again would not have been sufficient to recover solvency) was quickly ruled out given that an agreement could not be reached either with some members of the alliance or with the opposition party. After this failed attempt, fiscal adjustment was rejected by the new incoming minis ter ${ }^{28}$ (a big error in a situation in which sustainability was at stake), and replaced by a bewildering variety of stimulating fiscal arrangements (competitiveness plans), which were subject to several changes (another big error regarding credibility). Fiscal policy was swiftly changed in mid-2001, when it became clear that no additional external financing was going to materialize, by adopting a zero-deficit rule, and cutting transfers to provincial governments. Both measures put the political system to the test, and came too late to stop the crisis. Even though these announcements were made in an attempt to send a signal of improved sustainability, they were probably not credible inasmuch as political support was dim and the wealth redistribution struggle previously alluded to was already developing.

Debt Management. On the debt management side, under the perception that the country was only facing liquidity problems, the government engineered a massive debt swap in June 2001 to extend the maturity of the debt profile, but ended up validating extremely high interest rates which, in turn, confirmed expectations about an unsustainable fiscal position. This quickly led to expectations of a balance of payments crisis, which in the case of Argentina would be much more devastating given the existence of highly dollarized liabilities in the banking system.

\footnotetext{
${ }^{26}$ A package of about US\$40bn provided by official creditors.

${ }^{27}$ Mr. Ricardo Lopez-Murphy, a respected macroeconomist known for being fiscally strict was appointed to the Ministry of Economy.
} 
Another measure aimed at improving the fiscal position was the "voluntary"29 debt exchange introduced in late 2001, which reduced interest rates and extended debt maturity. But even if it was the right way to go because this policy was addressing the debt stock problem by reducing its present value, such measures should have been introduced much earlier. By then, the attack on the banking system and reserve loss were underway.

Exchange Rate Policy. To correct for RER misalignment, the convergence factor was introduced in mid-2001, basically a peg to a basket composed of dollars and euros in equal proportions ${ }^{30}$ that would become effective for all transactions when the parity between these currencies reached one. For trade transactions, though, dollars were exchanged at the ongoing dollar/euro basket rate, which amounted to a (fiscal) devaluation of about 8 percent. Unfortunately, the prevailing view was that misalignment stemmed exclusively from trade factors like the devaluation of the Real and the eurowhich ignored misalignment due to country risk considerations. From the previous analysis, it is clear that the peso's real depreciation obtained through fiscal devaluation, although in the right direction, was far from enough to correct the existing misalignment. The implementation of the convergence factor also had implications for exchange rate policy that may have contributed to the deposit run that would take place later, and the emergence of contingent liabilities that would further compromise the fiscal position.

\footnotetext{
${ }^{28}$ Mr. Domingo Cavallo, the father of the convertibility plan introduced in 1991, who had been highly successful in the fight against inflation and making the economy grow fast during the first presidency of Carlos Menem.

${ }^{29}$ Banks and pension funds were the main bondholders of the debt to be exchanged. Banks were persuaded to enter the exchange under pressure that their assets would otherwise have to be marked to market, something that could threaten their net worth position. Pension fund limits for holdings of public debt were increased to allow for placement of additional bonds.

${ }^{30}$ But surprisingly, not the Real, which would have been a key price to include if the main reason behind this change was to increase trade competitiveness.
} 
The convergence factor was mired in messy implementation, as there was no clear indication about when this new rule would become operational for all transactions. All that agents knew was that it would materialize whenever the dollar and the euro reached a parity of one to one. Moreover, this policy signaled to the market that the government was ready to loosen the shackles of the currency board and devalue. Fearful of the detrimental effects on bank assets that devaluation would cause via massive bankruptcies, depositors figured out that their assets (even if dollarized) were at stake, particularly given that the burden of a bank bailout was probably perceived as too big for the government to handle with its own resources. In this context, the signal given by the change in the currency board worsened expectations, something that would later lead to a massive deposit withdrawal and even larger loss of international reserves.

Monetary Policy. Perhaps the policy that most swiftly precipitated the balance of payments crisis (which, in turn, would weaken the fiscal position even further with the materialization of contingent liabilities), was the expansionary monetary stance held by the administration, even when the Currency Board kept the exchange rate firmly tied to the dollar. ${ }^{31}$ Expansionary reserve requirement policies were introduced, ${ }^{32}$ but quickly compensated for as a result of IMF pressure. The second tool available was domestic credit to commercial banks, which was sharply increased (see Figure 7). Central bank credit expansion explains about 53 percent of the staggering loss of reserves that took

\footnotetext{
${ }^{31}$ This policy was implemented after the dismissal of the central bank president, Pedro Pou. Although Convertibility required that the monetary base be backed by foreign assets, a share of these foreign assets could be composed of government paper in foreign currency, thus providing room for expansionary monetary policy.

${ }^{32}$ Bank excess reserves were accepted as part of reserve requirements, implying an expansion of lending capacity, but this was compensated for by increases in reserve requirement rates.
} 
place from April to December 2001. ${ }^{33}$ As discussed in Calvo, 2002a, under a Sudden Stop, a Central Bank will have incentives to hand its reserves to the credit constrained non-tradable corporate sector via credit expansion (a strategy that requires keeping a fixed exchange rate); but this may be a risky policy because it is not at all clear that reserves will end up in the hands of those who need them the most. There is a high chance that the sectors more likely to receive the proceeds from credit expansion (the public sector and prime borrowers with access to international markets, who represent a lower risk to banks) will end up unwinding their dollar debts, something that could be highly beneficial in light of upcoming devaluation. Thus, reserves are lost and there is little relief for those originally targeted by the Central Bank.

Not all credit expansion reflected the heterodox monetary position. As it turns out, soon after the government gave these expansionary signals, deposits began to decline sharply (about 18 percent between April and December 2001), which allegedly demanded central bank intervention in order to prevent a massive crash of the banking system. But, in any case, the question still remains as to what led the central bank to accommodate deposit withdrawal so swiftly, when the dominant theory was that foreign-owned banks would provide the necessary liquidity.

As crisis brewed, deposits fled the system and composition changed in favor of private banks, most of which are foreign-owned. Thus, depositors seem to have bought the theory-which constituted the intellectual basis behind bank denationalization since at least 1995-that foreign-owned banks would not let their subsidiaries go under. The central bank responded by providing support to the official sector. Deposits in those banks far exceeded international reserves. Thus, the realization that the central bank was

${ }^{33}$ Reserves are net of US\$4 billion in IMF loans. 
ready to bail out state-owned banks reinforced the expectation that the currency board's days were numbered. To further complicate matters, the central bank increased the reserve requirement of deposit-receiving banks in order to sterilize credit expansion (marginal reserve requirements were set at 75 percent). This sent a clear signal to foreign banks that they might be differentially treated, and their assets eventually confiscated, completely neutralizing the "lender of last resort" role that those banks were supposed to play. $^{34}$

Figure 7

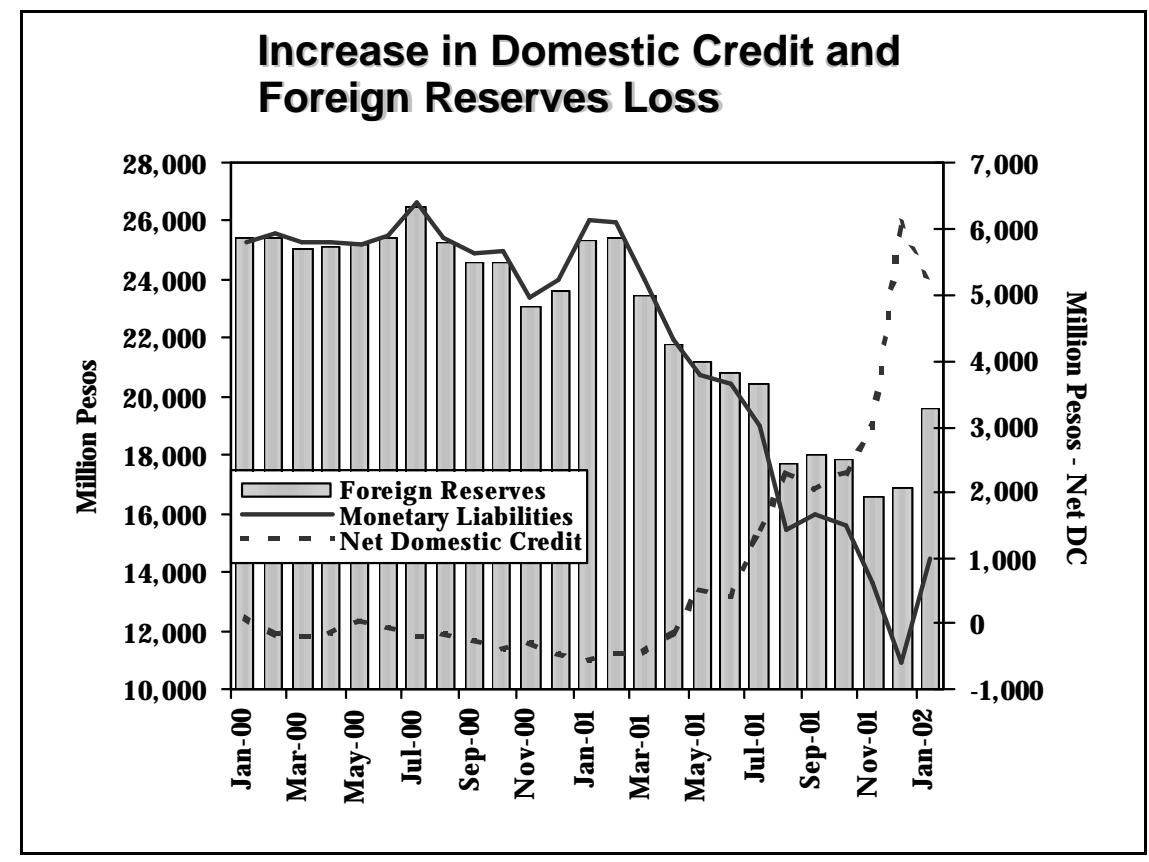

Source: Central Bank of Argentina (BCRA).

\footnotetext{
${ }^{34}$ Although many feared that foreign banks typically would not behave as shock smoothers, bringing along necessary resources to finance a bank run, the case of Uruguay may be relevant proof that when rules of operation are not changed and contracts are not repudiated, foreign banks may have incentives to come up with the necessary resources.
} 